Dr DAVOR KOVAČIĆ, naučni saradnik Hrvatski institut za povijest

\title{
NAČINI IZLASKA ZATOČENIKA IZ LOGORA SMRTI JASENOVAC I STARA GRADIŠKA 1941-1945.
}

\begin{abstract}
APSTRAKT: U članku se analiziraju načini izlaska zatočenika iz logora Jasenovac i Stara Gradiška u razdoblju 1941-1945. godine. Na primjerima izlaska iz logora pokušava se ukazati na pristup bivše jugoslavenske historiografije koja je istražujući problematiku jasenovačke skupine logora težište uvijek stavljala uglavnom na proučavanje partijske organizacije i broj žrtava u logoru, dok su ostali segmenti ove problematike uključujući i puštanje zatočenika iz logora bili zapostavljeni i prikazivani tek kao posve rijetka i slučajna pojava.
\end{abstract}

Ključne riječi: Jasenovac, Stara Gradiška, logori, Nezavisna Država Hrvatska (NDH), ustaše, zatočenici

U radovima i istraživanjima problematike koncentracijskog logora Jasenovac u bivšoj Jugoslaviji dominirali su politički ciljevi. Sukladno tome težište je gotovo uvijek stavljano na proučavanje rada partijske organizacije $\mathrm{u}$ logoru, te na broj ubijenih, poginulih i umrlih u logoru, dok su ostali aspekti istraživanja vezani za logore bili zanemareni. Naime, osnovne nesuglasice, dvojbe i kontroverze $u$ vezi s Jasenovcem odnose se s jedne strane na stvarni karakter logora, odnosno da li je to bio logor smrti, uspostavljen prema nacističkim uzorima. Pojedini autori koji su istraživali ovu problematiku, logore razvrstavaju u dvije osnovne skupine: sabirni i radni. Prema toj podjeli sabirni logori su bili neka vrsta sabirališta uhićenika odakle su poslije nekog vremena bili odvođeni na druga mjesta ili stratišta. Radni logori bili su mjesta prisilnog i besplatnog rada logoraša, a u praksi su bili masovna gubilišta. U historiografiji je neosporno da je osnovna namjena jasenovačkog logora bila izoliranje, a zatim i uništenje rasno i nacionalnovjerski nepoželjnih skupina, Židova, Srba, Roma odnosno Cigana (pravoslavne vjere, dok su Romi muslimani uglavnom bili pošteđeni). Pored njih u jasenovački logori su dovođeni i članovi politički nepoželjnih skupina, prije svega pripadnici Narodnooslobodilačkog pokreta. S druge strane nesuglasi- 
ce, dvojbe i kontroverze oko Jasenovca posebno se odnose na ukupni broj žrtava u logoru. Ovo pitanje je od završetka Drugog svjetskog rata pobuđivalo veliko zanimanje šire javnosti kao i onih koji su se profesionalno bavili raznim aspektima jasenovačke problematike. Ipak treba istaknuti da je pitanje ukupnog broja žrtava koncentracijskog logora Jasenovac imalo značajniju političku i promidžbenu ulogu krajem osamdesetih i početkom devedesetih u vrijeme stvaranja novih država na prostoru bivše Jugoslavije. Neosporno je da koncentracijski logor Jasenovac kao najveći logor u NDH i jugoistoku Europe, predstavlja najveće stratište za pripadnike svih nacionalnosti u NDH koje su život okončale u logorima. Točan broj pogubljenih $\mathrm{u}$ koncentracijskom logoru Jasenovac još je uvijek nezavršena tema suvremene hrvatske, ali i srpske historiografije. Ovisno o metodološkom pristu$\mathrm{pu}, \mathrm{u}$ hrvatskoj historiografiji se broj pogubljenih $\mathrm{u}$ jasenovačkoj skupini logora kreće od 60.000 do 100.000 . U srpskoj historiografiji revizijom popisa Žrtve rata 1941.-1945 iz 1964. godine pojedini autori procjenjuju da je u jasenovačkoj skupini logora stradalo između 122.300 i 130.100 osoba. ${ }^{1}$

Međutim, namjera ovog članka nije baviti se navedenim temama o kojima postoji opsežna literatura, nego istražiti temu kojoj u hrvatskoj kao niti u srpskoj historiografiji nije posvećena odgovarajuća pozornost. ${ }^{2}{ }^{\text {Nai- }}$ me, načini izlaska zatočenika iz jasenovačke skupine logora u postojećoj znanstvenoj i memoarsko-publicističkoj literaturi bili su slučajno ili namjerno zapostavljeni.

Još za vrijeme trajanja Drugog svjetskog rata pojavila se publikacija Jasenovački logor (s podnaslovom: Iskazi zatočenika koji su pobjegli iz logora) u izdanju Propagandnog odsjeka AVNOJ-a, prosinac 1942. godine. Izdavači su u predgovoru istakli zahtjev da se argumentirano i objektivno iznesu činjenice i događaji u jasenovačkoj skupini logora. Naveden je iskaz bivšeg zatočenika Gabrijela Vintera, koji je u Jasenovcu obavljao dužnost kočijaša i koji je naveo: „Od 200 do 300 tisuća ljudi koji su prošli kroz jaseno-

${ }^{1}$ Dragan Cvetković, Stradanje stanovništva u logorima-numeričko istraživanje, Logori, zatvori i prisilni rad u Hrvatskoj/Jugoslaviji 1941-1945, 1945-1951, Zbornik radova, Zagreb 2010, 53.

${ }^{2}$ O Jasenovcu je do 2000. godine objavljeno 1106 knjiga, 1482 memoarskih zapisa i članaka te 106 zbirki i dokumenata. O obimnom popisu radova o Jasenovcu do 200. godine vidi: Jovan Mirković, Objavljeni izvori i literatura o jasenovačkim logorima, Banja Luka-Beograd 2002. Komentar o literaturi vidi: Petar Strčić, Jasenovac i ratni zločin, Rijeka, 2000. Od radova objavljenih poslije 2000. godine navest ćemo samo neke: Nataša Matušić, Jasenovac 1941-1945, Logor smrti i radni logor, Jasenovac-Zagreb 2003; Antun Miletić, Koncentracioni logor Jasenovac, knjiga IV, Jagodina 2007; Jasenovac, zbornik radova (uredio Zdravko Antonić), Banja Luka 2007; Srboljub Živanović, Jasenovac, odabrani radovi, članci, intervjui, govori i diskusije (uredio Todor Bjelkić), Beograd-London 2008: Mario Kevo, „Posjet poslanika Međunarodnog odbora Crvenog križa logorima Jasenovac i Stara Gradiška u ljeto 1944“, Časopis za suvremenu povijest 2/2008, Zagreb, 547-585. 
vački logor, na slobodu je pušteno jedva 20-30 ljudi. To su većinom Židovi sa ženama arijevkama. I to je bilo ranije, kada se puštalo na rješenje iz Zagreba pod prijetnjom smrtne kazne za pričanja o strahotama jasenovačkog pakla". ${ }^{3}$

U izdanju Vjesnika jedinstvene narodnooslobodilačke fronte, 1944. godine ipak je navedeno da je 1.000 žena pušteno iz starogradiškog logora, ali tek kao ilustracija nesrazmjera između ubijenih i preživjelih zatočenika odnosno zatočenica i djece jer se navodi da je „kroz starogradiški logor prošlo preko 80.000 žena, od toga je oko hiljadu od raznih bolesti umrlo, oko 2.-3.000 poslano u njemačku na rad, oko 1.000 pušteno iz logora, oko 400 se još nalazi tamo, a sve ostale su pobijene. Oko 10.000 djece je prošlo kroz logor, a na životu je ostalo tek nekoliko stotina“. ${ }^{4}$

Ovakav pristup o jasenovačkim logorima kao stratištima u koje se vrlo lako ulazilo, a teško ili nikako izlazilo nastavljen je u većini radova u razdoblju od 1945. do 1990. godine. Tako je primjerice bivši pukovnik JNA Antun Miletić u svojoj knjizi Koncentracioni logor Jasenovac 1941.-1945., I, II, Beograd 1986., III, Beograd 1987., istakao da su logori Jasenovac i Stara Gradiška bili „pakao" iz kojeg se nije izlazilo. Međutim, bez obzira na prethodno izrečenu konstataciju, A. Miletić je samo nekoliko stranica dalje u svoju knjigu uvrstio više izvornih dokumenata Otpusnica koji pokazuju da se iz logora izlazilo i to kako pojedinačno tako i skupno. Miletić je objavio nekoliko dokumenata koji pokazuju i dokazuju da se je iz starogradiškog logora ipak izlazilo npr. dokument broj 179 Odluka da se Suada Mesirlić otpusti iz koncentracionog logora Stara Gradiška na molbu njene majke od 16. ožujka 1944. godine). ${ }^{5}$

Dakle, već samo na temelju navedenih primjera jasno je da su zatočenici ipak povremeno puštani iz logora, a sporno, odnosno predmet istraživanja može biti jesu li ta puštanja bila rijetka i slučajna ili je to bila češća pojava sa različitim oblicima i intenzitetima puštanja za cijelo vrijeme trajanja ovog logora od 1941. do 1945. godine? Na ovo pitanje pokušao sam odgovoriti na osnovi razmatranja dostupnih i objavljenih dokumenata, zatim literature i novinskih članaka bivših zatočenika u kojima govoreći o svom boravku u logoru spominju i načine izlaska iz jasenovačke skupine logora. Također sam se koristio i sjećanjima i iskazima bivših zatočenika koje su dali u svezi sudskog procesa koji se vodio u Zagrebu 1999. godine protiv Dinka Ljubomira Šakića, (jednog od zapovjednika jasenovačkog logora) kao

${ }^{3}$ Jasenovački logor, izdanje Propagandnog odsjeka AVNOJ-a, 1942, 4.

${ }^{4}$ Koncentracioni logori, Dokumenti ustaškog terora, Izdanje Vjesnika jedinstvene narodnooslobodilačke fronte Hrvatske, 1944, reprint izdanja Spomen područje Jasenovac, biblioteka Poruke, knjiga 28, 114.

${ }^{5}$ Antun Miletić, Koncentracioni logor Jasenovac 1941-1945, knj. I, II, Beograd 1986, knj. III, Beograd 1987. 
i iskaz samog D. Šakića u dijelu u kojem govori o puštanju zatočenika iz logora. ${ }^{6}$

\section{Organizacija logorskog sustava u NDH}

Nijemci su već od prvih dana nakon uspostave NDH poticali ustaške vlasti da sami organiziraju koncentracijske logore. ${ }^{7}$ U suradnji odgovarajućih tijela Trećeg Reicha i ustaških redarstava ključan je bio višednevni boravak ravnatelja Ravnateljstva za javni red i sigurnost (RAVSIGUR) Eugena Dide Kvaternika i nekolicine njegovih najbližih suradnika u Glavnome uredu SS-a posljednjih dana svibnja i početkom lipnja 1941. Po prvim aktivnostima RAVSIGUR-a i ustaškog redarstva neposredno po povratku ustaškoredarstvene delegacije iz Njemačke može se zaključiti da su E. D. Kvaternik i suradnici dobili detaljne savjete o oblicima organiziranja koncentracijskih logora. ${ }^{8}$

Naime, usporedimo li NDH sa srpskom kolaboracionističkom državom Milana Nedića treba istaknuti da su vlasti NDH upravljale koncentracijskim logorima na svom teritoriju, dok su logorima u Srbiji upravljale njemačke okupacijske snage.

Organiziranje logora na teritoriju NDH može se podijeliti u dvije faze. Prva faza je bila kraća i trajala je do početka jeseni 1941. godine kada je bilo još puno improvizacija. Osnivali su se prvi logori koji su gotovo preko noći morali preuzimati veliki broj interniraca. To su bili logori Danica u Koprivnici, Kerestinec kraj Zagreba, Gospić, Jadovno na Velebitu, Slana i Metajna na otoku Pagu, Kruščica kraj Travnika. Prvi veliki logor nalazio se je u Drnju kod Koprivnice, smješten u napuštenim prostorima propale kemijske industrije „Danica“, po kojoj je i dobio ime. Prema nalogu Eugena Dide Kvaternika svim župskim i gradskim redarstvima od 8. srpnja 1941. godine trebalo se je sve grkoistočnjake i Židove slati u Gospić na dispoziciju Župskog redarstvenog Ravnateljstva u Gospiću, a nikoga više u koncentracijski logor „Danica“. Razlog takve odluke bio je u činjenici da je logor „Danica“ postao premali za sve veći broj zatočenika. Do kraja srpnja 1941. godine svi Židovi iz „Danice“, osim nekolicine koja je puštena kućama, otpremljeni su u Gospić. Isto tako i većina Srba je otpremljena u Gospić, izuzev, nekih, uglavnom pravoslavnih svećenika, koji su deportirani u Srbiju.

${ }^{6}$ Dinko Šakić je na suđenju u Zagrebu, u listopadu 1999. osuđen na 20 godina zatvora zbog počinjenog kaznenog djela protiv čovječnosti i međunarodnog prava-ratnog zločina nad civilnim stanovništvom.

${ }^{7}$ A. Miletić, $n$. dj., (knj. III.) 9-11.

${ }^{8}$ Narcisa Lengel Krizman, Ženski sabirni logori 1941-1942. godine, Povijesni prilozi 4, Zagreb 1985. 
Sa tako znatno smanjenim brojem interniraca logor „Danica“ je postojao do proljeća 1942. godine kada je raspušten. ${ }^{9}$

Prvotna namjera vlasti NDH o osnivanju koncentracijskih logora na Velebitu i otoku Pagu propala je zbog blizine talijanske vojne nazočnosti, zbog čega je traženo novo područje pogodno za tu namjenu. Naime, ti logori su bili smješteni na teritoriju Druge zone, koja je Rimskim ugovorima o razgraničenju između Kraljevine Italije i NDH od 18. svibnja 1941., pripala $\mathrm{NDH}$, ali dodatnim sporazumom je predviđeno da talijanska vojska može iz sigurnosnih razloga preuzeti cjelokupnu vlast, uključujući i civilnu. Kada je Kraljevina Italija službeno zatražila hitnu reokupaciju Druge zone, postalo je jasno da predstoji hitno povlačenje oružanih snaga NDH iz tog područja te evakuacija, odnosno likvidacija spomenutih logora. Do toga je i došlo 23. kolovoza $1941 .^{10}$

Zbog spomenutih razloga Eugen Dido Kvaternik, zapovjednik RAVSIGUR-a te zapovjednik kasnije osnovane Ustaške nadzorne službe (UNS), već sredinom mjeseca srpnja 1941. naredio je osnutak novog logora u koji bi se premjestili zatočenici iz talijanske Druge zone. ${ }^{11}$ Naime tražila se nova pogodna lokacija koja bi zamijenila gospićki logorski sustav sa mrežom logora i stratišta (Gospić, Jadovno, Pag). Za tu namjenu najviše je odgovarao teren u međurječju Save, Velikog Struga i Lonje, koji je presijecala željeznička pruga Novska-Dubica, a i sam Zagreb je bio relativno blizu. Uz to, nedaleko se je nalazila i kaznionica u Staroj Gradiški koja je bila uključena $\mathrm{u}$ jasenovački sustav logora. Ova skupina logora sastojala se je od pet logora. Logor I. Krapje, logor II. Bročice, logor III. Jasenovac, logor IV. Kožara i logor V. Stara Gradiška. ${ }^{12}$

Druga faza osnivanja i organiziranja logora u NDH počinje osnivanjem i razvijanjem jasenovačke skupine logora u jesen 1941. godine. Izu-

${ }^{9}$ A. Miletić, n. dj., (knj. III) 9-11.

${ }^{10}$ Ivo Goldstein, suautor Slavko Goldstein, Holokaust u Zagrebu, Zagreb 2001, 291. O sustavu logor Gospić, Jadovno, Pag vidi opsežnu monografiju: Đuro Zatezalo, Jadovnokompleks ustaških logora 1441., knjiga I-II, Muzej žrtava genocida, Beograd, 2009.

${ }^{11}$ Mario Kevo, „Počeci logora Jasenovca“, Scrinia Slavonica, Godišnjak Podružnice za povijest Slavonije, Srijema i Baranje Hrvatskog instituta za povijest, Slavonski Brod 2003, 473.

${ }_{12}$ Anđelko Barbić, „Počeci osnivanja kompleksa koncentracionih logora u Jasenovcu“, Slavonski povijesni zbornik, Slavonski Brod, 1987, 1-2, 72. Kompleks koncentracijskih logora jasenovačke skupine je sa Starom Gradiškom obuhvaćao oko 210 km/2. U daljnjem razvitku kompleksa jasenovačkih logora formirali su se i privremeni manji logori: logor V. (ciganski) u selu Uštica, na ušću Une u Savu, koji je postojao od prve polovice 1942. godine, pa do travnja 1945. godine. Numeracija ovog logora podudara se s logorom V. Stara Gradiška, ali je upotrebljavana kao interna oznaka za logor na užem području Jasenovca. Logor VI. (ženski radni logor) Mlaka, nalazio se je $12 \mathrm{~km}$ od Jasenovca prema Staroj Gradiški, gdje su za vrijeme sezonskih poljoprivrednih radova dovođene zatočenice iz ostalih logora. Usp. Zlata Živaković-Kerže, Stradanja i pamćenja: holokaust u Osijeku i život koji se nastavlja, Osijek, 2006, 111. 
zmemo li jasenovačku skupinu logora, svi ostali su postojali kraće vrijeme. Osnivani su prema određenoj namjeni i uslijed određenih okolnosti i ubrzo su bili likvidirani, često i prije nego se u njima mogla provesti određena organizacija života.

Zakonskom odredbom o upućivanju nepoćudnih i pogibeljnih osoba na prisilni boravak u sabirne i radne logore NDH, objavljenoj u Narodnim novinama NDH 26. studenog 1941., ustaške su vlasti formalno-pravno ozakonile sustav logora. Na temelju prvog članka ove odredbe u sabirne i radne logore su upućivane „nepoćudne osobe koje su pogibeljne za javni red i sigurnost, ili koje bi mogle ugroziti mir i spokojnost hrvatskog naroda". ${ }^{13} \mathrm{Od}$ tada su internici u logore slani na temelju ove zakonske odredbe koja je sadržavala i detaljno razrađen upravno-administrativni postupak. Okružnicom RAVSIGUR-a od 30. prosinca 1941. obaviještene su sve velike župe da "Zapovjedničtvo sabirnih logora" neće i ne smije primati u logor ni jednu osobu za koju nije izdana odluka o upućivanju u logor iz Ustaške nadzorne službe, Ured I. Ljudi su slani na preodgoj u sabirne i radne logore uglavnom zbog pristajanja uz komunizam i partizane. Primjerice N. M. zbog veze s odmetnicima, odnosno komunistima uhitila je talijanska vojska za vrijeme operacija na području Kotarske oblasti Vojnić. Međutim, u logore se odlazilo i iz drugih razloga, primjerice radi veza s četnicima Draže Mihailovića. ${ }^{14}$

Nakon upućivanja u logor župska je redarstvena oblast Uredu I. UNS-a trebala podnijeti tzv. „Prijedlog o prisilnom boravku u logoru“ te priložiti dosje te osobe. Tada je Ured I. UNS-a donosio konačnu odluku protiv koje nije bilo pravnog lijeka. Potom je izdavana tzv. „Uputnica“, a nakon prijema osobe, logor je morao izdati posebnu „Potvrdu." 15

Župske redarstvene oblasti toga su se pridržavale, ali jedinice Ustaške vojnice i Ustaške obrane nisu. U Jasenovac i Staru Gradišku sve do listopada 1942. u valovima su stizali brojni transporti novih zatočenika bez ikakvih odluka i popratnih papira. ${ }^{16}$ Prema iskazu Ljube Miloša, visokog ustaškoga dužnosnika u jasenovačkom logoru, broj zatočenika koji su upućivani s odlukama župskih redarstava bio je puno manji od onih koji su upućivani u skupnim transportima bez odluka. Prema njegovu iskazu te su osobe odmah odvođene na likvidaciju. ${ }^{17}$

\footnotetext{
${ }^{13}$ Zbornik zakona i naredaba NDH, sv. I. (1941), 968.-969.

${ }^{14}$ Hrvatski državni arhiv (HDA), Redarstvena oblast (RO) za grad Zagreb, Policijski kartoni.

${ }^{15}$ HDA, Ministarstvo pravosuđa i bogoštovlja Nezavisne Države Hrvatske (MPB NDH), Odjel za pravosuđe, Okružnica: Postupak sa sa osobama koje su upućuju u radne i sabirne logore. I-55/1941. br. 92859.

${ }^{16}$ I. Goldstein, S. Goldstein, n. dj., 321.

${ }^{17}$ Vidi opširnije: Davor Kovačić, „Zapovjednici i dužnosnici jasenovačke skupine logora 1941.-1945“., Časopis za suvremenu povijest, Zagreb, 32/2000., br. 1., 105.-106.
} 
Lj. Miloš u iskazu je naveo da je „Luburić odredio da u Jasenovcu brojno stanje uvijek varira oko 3.000, jer je ta cifra uglavnom bila dovoljna da podmiri sve potrebe radne službe (...) Bilo je slučajeva, kad je logor brojio i po 5.000 zatočenika, ali dotična cifra nije mogla dulje trajati, jer se je u takvom slučaju vršila likvidacija viška." 18

Zapovjedništvo sabirnih logora nije imalo uvida niti utjecaja u obavljanju likvidacija, nego je o njima izravno odlučivao i rukovodio Ured III., odnosno Vjekoslav Maks Luburić. Predstojnik Kotarske oblasti Novska, Aleksandar Benak je o učestalim likvidacijama u logoru izvijestio tadašnjeg ministra unutarnjih poslova A. Artukovića. Nakon kraćeg vremena u Jasenovac je došao Eugen Dido Kvaternik i obišao logor. Navratio je s Vjekoslavom Maksom Luburićem i u Kotarsku oblast Novska. Tada je naredio je da svaki slučaj smrti u logoru treba službeno ustanoviti predstojnik kotarske oblasti A. Benak kad ga o tome izvijesti i pozove Luburić. Službenom utvrđenju smrti trebala je nazočiti i osoba iz općine, suda te općinski liječnik. Međutim, u praksi je smrt zatočenika odlazio konstatirati kotarski predstojnik (Benak), logorski liječnik (zatočenik) i katkad (ne uvijek) izaslanik općine. Pregledom leša zatočenika, logorski liječnik bi ustanovio smrt. Na temelju povijesti bolesti ustanovio bi i uzrok smrti, u većini slučajeva to je bila dizenterija, staračka slabost ili angina pectoris. Pregledu je obično bio nazočan i neki ustaški dužnosnik iz logora (Luburić je bio nazočan samo jednom). ${ }^{19}$

Suprotno Benakovu iskazu, preživjeli zatočenici jasenovačkog logora, ističu da, kada bi netko od zatočenika koji su bili uvedeni u logorske knjige, (odnosno za koje je postojala kartoteka), bio ubijen ili umro od bolesti, napravio bi se zapisnik o smrti. Liječnici logoraši morali su tada postaviti bilo kakvu dijagnozu, a da mrtvog zatočenika uopće nisu vidjeli. U kartoteku i knjige uvelo bi se: „umro toga i toga dana.“ Ti zapisnici vjerojatno su u prijepisu odašiljani Uredu I. u Zagreb, ali obitelj ubijenih ili umrlih o tome uopće nije bila obaviještena. ${ }^{20}$ Prema nekim iskazima, zatočenici su bili ubijani i nakon što je stigla odluka da ih se iz logora preprati na slobodu. U isto vrijeme stigao bi i drugi nalog, da se zatočenik potajno ubije, a kroz popis zatočenika provede da je u određenom vremenskom roku umro od bolesti. ${ }^{21}$

Trajanje boravka u sabirnim logorima nije moglo biti kraće od šest mjeseci, niti duže od tri godine. Ured I. UNS-a, mogao je u svako vrijeme ukinuti svoju odluku o upućivanju pojedinih osoba na prisilan boravak $u$

${ }^{18}$ HDA, Republički sekreterijat unutarnjih poslova Socijalističke Republike Hrvatske, Služba državne sigurnosti (RSUP SRH SDS), Dosje Ljubo Miloš, 69.-70, 78.-79.

${ }^{19}$ HDA, RSUP SRH SDS, 013.2.5,.., A. Benak, kut. 51., 7.- 8.

${ }^{20}$ Đ. Miliša, U mučilištu pakla Jasenovca, Zagreb, 1945, 170.

${ }^{21}$ HDA, RSUP SRH SDS, 013.2.5, A. Benak, kut. 51., 7.-8. 
sabirne logore, a isto tako je mogao u svako vrijeme po slobodnoj procjeni smanjiti trajanje boravka pojedine osobe u sabirnom logoru. Vrijeme provedeno u pritvoru upravnih oblasti i redarstava prije donošenja odluke o upućivanju pojedine osobe na prisilni boravak u sabirne logore, uračunavalo se je u vrijeme trajanja boravka pojedine osobe u sabirnom logoru. ${ }^{22}$

Treba istaknuti da je Zakonska odredba o upućivanju nepoćudnih i pogibeljnih osoba promijenjena dva puta. Prva nadopuna ove zakonske odredbe je proglašena 27. veljače 1943. i sastojala se u reguliranju statusa državnih i samoupravnih službenika ako budu upućeni na prisilni boravak u sabirne i radne logore, odnosno predviđala je njihovo otpuštanje iz državne službe kao i lišavanje prava na mirovinu. ${ }^{23}$ Druga promjena provedena je 12. siječnja 1945. kada je poglavnik Ante Pavelić potpisao Zakonsku odredbu o promjenama i nadopunama Zakonske odredbe o upućivanju nepoćudnih i pogibeljnih osoba u sabirne i radne logore. Odredba je stupila na snagu s danom objave u Narodnim novinama. Značajno je napomenuti da je izvornoj zakonskoj odredbi pridodan članak 5. kojim je utvrđeno da se osobama upućenima na prisilni boravak u sabirne i radne logore može u korist NDH oduzeti pokretna i nepokretna imovina, ali ne u vrijednosti većoj od pola milijuna kuna. Ova odredba se mogla primjeniti i na osobe koje su upućene u logore i prije ove zakonske odredbe. ${ }^{24}$

Početkom 1943. ukinućem UNS-a stvoreno je Glavno ravnateljstvo za javni red i sigurnost (GRAVSIGUR) u čijem se je sastavu nalazio Odjel za javnu sigurnost - Odsjek za političko redarstvo. Njegovi zadaci su bili: suzbijanje vanjske i unutarnje protudržavne djelatnosti, upućivanje osoba u sabirne i radne logore, izdavanje odluka o oduzimanje imovine, suzbijanje nasilnih kažnjivih čina protiv države, pojedinih osoba ili imovine. ${ }^{25}$

Tako je GRAVSIGUR 11. travnja 1945. propisao mjere u predmetu otpreme sumnjivih i nepoćudnih osoba u sabirne i radne logore. U okružnici koju je potpisao glavni ravnatelj GRAVSIGUR-a Erih Lisak navodi se da su prigodom upućivanja nepoćudnih osoba u sabirne i radne logore primijećene osobito u zadnje vrijeme neke nepravilnosti. Nadalje se kaže: „U nadležnoj radnoj jedinici ovog Ravnateljstva stavljali su se priedlozi da se neke osobe upute $u$ logore, a da za to nisu predlagani baš osobito važni razlozi, niti je postojala potreba da se takove osobe šalju u logor, tim više što zato postoje druge mogućnosti kažnjavanja. Kako je poznato sabirni logor u Jasenovcu u više je navrata bombardiran po neprijateljskim zrakoplovima, a osobito vrlo teško prigodom posljednjeg napadaja pred Uskrs, tako da u

\footnotetext{
${ }^{22}$ A. Barbić, $n$. dj., 72.

${ }^{23}$ Narodne novine, 27. I. 1945.

${ }^{24}$ M. Kevo, Počeci logora Jasenovca, 17.

${ }^{25}$ HDA, RSUP SRH SDS, GRAVSIGUR NDH, kut. 51., 126.
} 
dogledno vrijeme neće biti moguće nikoga otpremiti u navedeni logor na prisilni rad. ${ }^{26}$ Obzirom na to smatra potrebnim ovo Glavno ravnateljstvo odrediti da se nadležnom odsjeku ubuduće stavljaju prijedlozi za upućivanje u logor samo za takve osobe koje su zaista štetne za probitke NDH i čije trajanje bi se obzirom na konkretan slučaj moralo predvidjeti najmanje dvije godine. Jednom riečju, sve područne oblasti, neće ovom ravnateljstvu stavljati priedloge za one slučajeve kada to sam čin okrivljenoga kao i sve olakohotne okolnosti budu imperativno tražile, već će se takovi slučajevi prosuđivati na temelju nadopuna Zakonskoj odredbi o upućivanju nepoćudnih osoba u sabirne i radne logore tj. oduzećem imovine koja kako je poznato može ići i do 500.000 .000 kuna. Zatvori redarstvenih oblasti su prenatrpani, a isto tako i postojeći sabirni logor u Lepoglavi pa se radi toga ubuduće samo one najteže slučajeve imade predlagati za logor, a ostale kažnjavati isključivo novčanim kaznama. “27

\section{Puštanje putem pomilovanja i amnestijom zatočenika}

Jedna od prvih skupina zatočenika puštena na slobodu bila je skupina intelektualaca iz Zagreba koji su bili optuženi da su masoni koji su djelovali u Kraljevini Jugoslaviji. Ova skupina intelektualaca uhićena je u noći 10./11. studenog 1941. godine Zagrebu i ujutro 11. studenog upućena u Jasenovac, a dan kasnije dovedeni su u starogradiški logor. U toj skupini se nalazilo 37 osoba optuženih za masonstvo: dr. Ante Barac, sveučilišni profesor, dr. Josip Badalić, ravnatelj sveučilišta knjižnice i sveučilišni profesor ruske književnosti, dr. Ivo Belin, viceguverner Narodne banke Jugoslavije, Krešimir Brovet, veletrgovac, Mirko Breyer, književnik i križar, dr. Zvonimir Bratanić, ravnatelj „Našićke“, Krešimir Baranović, direktor zagrebačke opere, dr. Mirko Deanović, sveučilišni profesor, dr. Branko Dragišić, sveučilišni profesor, dr. Nikola Fink, sveučilišni profesor, ravnatelj zoološkog muzeja, Milan Glazer, ravnatelj Središnjeg ureda za osiguranje radnika, ing. Juraj Horvat, sveučilišni profesor, Radoslav Horvat, knjižar, ing. Branimir Iveković, šef arhitekta Središnjeg ureda za osiguranje radnika, ing. Mate Jurković, šef Građevinskog ureda grada Zagreba, dr. Ivo Ivančević, sveučilišni profesor, dr. Marko Kostrenčić, sveučilišni profesor i bivši ministar, dr. Vlatko Katičić, advokat, dopisni član JAZU, dr. Janko Koščević, advokat, pravni zastupnik Jugoslavenske banke, dr. Grga Novak, sveučilišni profe-

${ }^{26}$ Marica Karakaš Obradov, Anglo - američka bombardiranja Hrvatske u Drugom svjetskom ratu, Saveznički napadi na Nezavisnu Državu Hrvatsku 1943.-1945., Zagreb, 2008., 234. Dana 30. ožujka 1945. u dva navrata je bombardiran koncentracijski logor Jasenovac te je gotovo potpuno porušen i spaljen.

${ }^{27}$ Državni arhiv u Zagrebu (DAZ), Kotarska oblast Zagreb, sig. 3. 
sor, Zvonimir Maravić, sudac Stola sedmorice, dr. Ante Mudrinić, ravnatelj Okružnog ureda za osiguranje radnika, ing. Božidar Prikril, direktor Električne centrale, Vladimir Očić, načelnik Ministarstva trgovine, dr. Jozo Poduje, advokat, predsjednik Rotary kluba, Dušan Plavšić, tajnik Saveza novčanih zavoda, Jaskov Vivoda, savjetnik Ministarstva trgovine, dr. Marko Ružić, sudac Stola sedmorice, dr. Stanko Švrljuga, predsjednik Udružene banke i bivši ministar, ing. Ferdinard Šega, građevinski poduzetnik, dr. Ljudevit Špaljt, sveučilišni profesor, dr. Franjo Tućan, sveučilišni profesor, dr. Slavko Zimmermann, predsjednik farmaceutske komore, dr. Fran Zavrnik, sveučilišni profesor, ing. Vlado Žepić, ravnatelj državnih električnih poduzeća. U toj skupini bili su i intelektualci koji nisu pripadali masonima: Ilija Jakovljević, odvjetnik, novinar i književnik, Karlo Kovačević, književnik i saborski zastupnik, Đuka Kemfelja, saborski zastupnik. ${ }^{28}$

Hrvatski intelektualci optuženi za masonstvo su po naređenju samog Luburića imali poseban, povlašteni tretman u logoru. Nisu morali obavljati nikakve poslove i nije ih se tuklo. Izlazili su na šetnje, okolo same bolnice, jedan iza drugoga, bez zastoja, pod stražom Ante Vrbana ili Nikole Gagre. Za hranu su najčešće dobivali kupus i grah, uvijek s dovoljno kruha. Kasnije su smijeli dobivati tjedno po jedan paket hrane, pisati dopisne karte uz javljanje rodbini najnužnijeg, da im je u logoru dobro. Čitanje knjiga im je bilo zabranjeno, a novine su mogli nabavljati, jer im novac nije bio oduzet kao ostalim zatočenicima. Prvi koji je pušten na slobodu od ove skupine intelektualaca bio je dr. Stanko Švrljuga, na Božić 1941. godine. U veljači 1942. godine pušteni su iz logora dr. Zvonko Bratanić, Krešimir Baranović, dr. Branko Dragišić, dr. Natko Katičić, Đuka Kemfelja i prof. Ljudevit Tomašić u svezi sa sazivom Hrvatskog državnog sabora 23. veljače 1942. godine. Početkom travnja iste godine pušteni su svi zatočenici iz ove skupine osim Ante Mudrinića, Dušana Plavšića, Karla Kovačevića, Frana Zavrnika i Ilije Jakovljevića. Kasnije su Mudrinić i Kovačević likvidirani, a posljednji su pušteni na slobodu Zavrnik i Jakovljević 17. prosinca 1942. godine. Uprava logora Jakovljevića do tada nikako nije htjela osloboditi, iako je iz Zagreba za njega stigla odluka da ga se pusti. To su opravdavali tako što su u Zagreb poslali izvještaj u kojem su naveli da je obolio od tifusa. Jakovljević je trebao biti ubijen 22. lipnja 1942. kada i dr. Ante Mudrinić, ali se uspio spasiti kazavši da piše roman o Hercegovini, (iz koje je uostalom i bio rodom), a koji mu je odobrio zapovjednik, ustaški natporučnik Branko Slipčevič. Ta izjava mu je poštedila život jer je otuda bio Nikola Gagro kao i većina ustaša u logoru. ${ }^{29}$

\footnotetext{
${ }^{28}$ Đ. Miliša, n. dj., 183.-185.

${ }^{29}$ Isto, 192.
} 
Smjenom Luburića i dolaskom novog povjerenika Stanka Šarca, Jakovljević je 17. prosinca 1942. godine pušten iz logora i odveden u Zagreb u zatvor na Savskoj cesti odakle je pušten kući. Poslije izlaska iz logora napisao je svojevrsni romanizirani dnevnik, gdje je opisao sve suprotnosti i okrutnosti života u starogradiškom logoru. Rukopis tog dnevnika otkriven je i objavljen pod naslovom Konclogor na Savi, Zagreb, 1999.

Hrvatski intelektualci optuženi za masonstvo su prema izjavi Dinka Šakića poslije izlaska iz logora napisali pismo zahvale za humano postupanje u logoru. ${ }^{30}$ Antun Barac je o svom boravku u logoru napisao Bijeg od knjige, Zagreb 1965., a podnaslov knjige se zove Zabilješke iz godine 1943. i 1944. Središnji dio čine zapisi i pjesme pod naslovom KZSTG (Kazneni zavod Stara Gradiška). Većina ovih zapisa i pjesama nastala je u samom logoru, na komadićima papira. Upravo je nestašica papira bila razlog da Barac piše $u$ logoru i pjesme, jer je u njima mogao jednostavnije i kraće izraziti neke svoje doživljaje i osjećaje.

Zatočenici su iz starogradiškog logora najčešće puštani prilikom obilježavanja značajnijih datuma kao što su državni praznici i blagdani, te poglavnikov rođendan i imendan. Tako je u čast konstituiranja spomenutog Hrvatskog državnog sabora, odlukom poglavnika od 11. veljače 1942. godine pušteno na slobodu iz logora Jasenovac i Stara Gradiška ukupno 17 osoba. Pored navedenih pet intelektualaca iz Zagreba, koji su pušteni iz starogradiškog logora, kućama je pušteno 12 osoba: Vladimir Klubička iz Končanice, Pero Kovačević iz Daruvara, Josip Balaš iz Goveđa, Đuro Kovačević iz Daruvara, Miroslav Klemenčić iz Karlovca, Ivan Krznar iz Karlovca, Adam Dujmović iz Otočca, Humberta Živni iz Otočca, Mijo Kokot iz Dugog Sela, Matija Matijević iz Daruvara, dr. Ante Bošnjaković iz Sarajeva i Hasan Grabčanović iz Bijeljine. ${ }^{31}$

Jedan od rijetkih zagrebačkih Židova za kojeg je poznato da je oslobođen iz jasenovačkih logora bio je kipar Viktor Samuel Bernfest, inače u braku s „arijevkom“. Po svemu sudeći razlog puštanja bio je taj što je zagrebački oftalmolog dr. Vilko Panac, inače Bernfestov šogor, operirao dvostru$\mathrm{ku}$ očnu mrenu jednom rođaku Ante Pavelića i nekim višim ustaškim dužnosnicima. ${ }^{32}$

Istaknuti judaist Lavoslav Šik pušten je početkom 1942., iz Jasenovca na Stepinčevu intervenciju, ali je ubrzo opet uhićen i deportiran u Jasenovac, gdje je odmah ubijen. ${ }^{33}$

30 „Nemam se čega braniti“, Vjesnik, Zagreb, 25. VI. 1999.

31 "Putem milosti pušteni na slobodu iz sabirnog logora“, Hrvatski narod, Zagreb, 25. II. 1942. U ovoj obavijesti o puštanju nije precizno navedeno koja od ovih osoba je puštena iz Jasenovca, a koja iz Stare Gradiške.

${ }^{32}$ I. Goldstein, S. Goldstein, $n$. dj., 329.

${ }^{33}$ Isto. 
Puštanja zatočenika iz jasenovačke skupine logora putem pomilovanja bilo je i tijekom 1943. i 1944. godine, kada je pušten i Mirko Peršen koji je u koncentracijskom logoru Stara Gradiška boravio od 31. lipnja 1943. godine do 19. studenog 1944. godine kada je pušten kući. ${ }^{34}$

Prema svjedočenju D. Šakića jednom je prilikom (Šakić nije naveo kojom) iz Jasenovca i Stare Gradiške pušteno 160 dalmatinskih partizana na slobodu jer je uprava logora vidjela „da su dobri ljudi i Hrvati“ ${ }^{35}$

Bivši zatočenici koncentracijskog logora Jasenovac ističu da su logoraši uglavnom završavali pod zemljom, ali bilo je i slučajeva puštanja zatočenika i puno prije isteka kazne zadržavanja boravka u logoru. Naime, izdržavši kaznu od najmanje tri mjeseca, a najviše od tri godine, rijetko tko se puštao na slobodu u određeno vrijeme, dok je više bilo slučajeva da su pojedini logoraši puštani mnogo prije isteka presude. Priličan broj osuđenika na kraće vremenske kazne, nakon izdržanog roka, po propisanoj je proceduri bio otpušten iz logora. ${ }^{36} \mathrm{U}$ nešto boljoj situaciji od ostalih, nalazili su se kvalificirani radnici, zanatlije i industrijalci jer su za njih znali intervenirati povjerenici poduzeća Ureda za podržavljeni imetak kako bi se u istima nesmetano nastavila proizvodnja.

U nadi da su nepravedno zatočeni mnogi ljudi su intervenirali za zatočene osobe, odnosno, prijatelje znance, rodbinu, iako je zakonskom odredbom od kraja studenog 1941., određeno da nema pravnog lijeka odluci o upućivanju u logor. Tu se najčešće radilo o intervenciji izvana, pa je zbog toga odlučeno da se molbeni postupak može obavljati jedino putem župskih redarstvenih oblasti koje će molbe za otpust iz logora na odlučivanje proslijediti zapovjedništvu Ustaške nadzorne službe. ${ }^{37}$

Molbe su se podnosile i na Ured poglavnika, gdje je bilo raznih intervencija i one su se prvenstveno odnosile na priznanje arijevskog prava. ${ }^{38}$ Putem intervencija i relativno visoki ustaški dužnosnici pokušavali su osloboditi zatočenike iz logora. Tako je primjerice Viktor Ramov, referent za molbe i žalbe u predsjedništvu vlade intervenirao kod ministra unutarnjih poslova Andrije Artukovića da se iz logora Jasenovac pusti devet osoba iz Ludbrega koji su tamo bili zatočeni. Artuković je odgovorio, uz ispriku da mu nažalost ne može pomoći jer o tome odlučuje Eugen Dido Kvaternik i da on nema nikakve nadležnosti. Drugom prilikom kada je Kvaternik već bio smijenjen i zamijenio ga Ljudevit Zimpermann, Ramov je ponovo tele-

\footnotetext{
${ }^{34}$ Vidi: Mirko Peršen, Ustaški logori, Zagreb, 1990.

${ }^{35}$ Slobodna Dalmacija, Split, 29. VI. 1999.

${ }^{36}$ I. Goldstein, S. Goldstein, $n$. dj., 322. Autori navode kako među njima gotovo ni-

${ }^{37}$ Đ. Miliša, $n$. dj., 294.

38 „Upozorenje ureda Poglavnika“, Hrvatski narod, Zagreb, 28. VI. 1941.
} kada nije bilo Židova ili Židovki. 
fonski intervenirao kod Artukovića koji je izjavio da sada može udovoljiti njegovoj molbi i da će ti ljudi biti pušteni, što je Zimpermann ubrzo i učinio. ${ }^{39}$

Naime, još od prvih dana uspostave NDH, Eugen Dido Kvaternik je zauzeo suprotan stav prema Andriji Artukoviću, ministru unutarnjih poslova. Kvaternik je sve referirao izravno Paveliću potpuno zaobilazeći ministra Artukovića. Ministar unutarnjih poslova Artuković nije imao nikakve ingerencije nad RAVSIGUR-om i UNS-om kojim je rukovodio E. D. Kvaternik. On je u u stvari radio što je htio i prema izjavi visokih ustaških dužnosnika Stjepana Vukovca i Vladimira Židovca, bio je zapravo pravi gospodar $\mathrm{u}$ ministarstvu unutarnjih poslova. ${ }^{40}$

Osim ministra unutarnjih poslova Artukovića na puštanje iz logora utjecali su mnogi visoki dužnosnici, ponekad čak i sam poglavnik Pavelić, ali često bez uspjeha. Tako se je primjerice veliki župan Velike župe Zagorje Stjepan Uroić sukobio sa zapovjednicima logora Jasenovac i Stara Gradiška kada je u svibnju 1942. godine iz sela Lađevac kod Okučana u logor odvedena skupina od 130 žena i djece. Osobno je odnio Paveliću popis uhićenih moleći da se odmah oslobode. Pavelić je navodno naredio njihovo oslobađanje, ali iz logora je pušteno tek dvadesetak osoba. ${ }^{41}$

Za skladatelja i glazbenog kritičara Žigu Hirschlera, koji je deportiran u rujnu 1941. godine u Jasenovac, zauzela se nekolicina istaknutih hrvatskih glazbenika i umjetnika, između ostalih i Boris Papandopulo i Lovro Matačić. Iako je Židovski odsjek Ustaškog redarstva zahtijevao da se Hirschler pusti iz logora, sve je bilo uzalud. ${ }^{42}$

Čak ni pozitivno mišljenje poglavnikova Ureda nije uvijek značilo spas, jer se događalo da se ustaše na taj dokument nisu obazirale te bi osoba i dalje ostala zatočena u logoru ili bi bila ubijena. ${ }^{43}$

Često puta nisu oslobađani niti posjednici tzv. Dopustnice o nesmetanom boravku na teritoriju NDH, a na spomenute molbe uglavnom su stizali vrlo jednostavni odgovori, poput: „ne može se pustiti na slobodu“, „ne rješava se pošto je zastarjela" ili je na samom dokumentu rukom nadopisano "ne odobrava se“. ${ }^{44}$

${ }^{39}$ HDA, RSUP SRH SDS, 013.144. kut., 50, Dosje A. Artukovića, Zapisnik o ispitivanju svjedoka Viktora Ramova, kut. 54., 472.

${ }^{40}$ I. Goldstein, S. Goldstein, $n$. dj., 584. $2001, .73$.

${ }^{41}$ Nada Kisić-Kolanović, NDH i Italija. Političke veze i diplomatski odnosi, Zagreb,

${ }^{42}$ I. Goldstein, „Solidarnost i pomoć Židovima u Hrvatskoj“, Radovi 34-35-36, Zavod za hrvatsku povijest Filozofskog fakulteta, Zagreb, 2002.-2004., 213. Vidi: I. Goldstein, S. Goldstein, $n$. dj., 633.

${ }^{43}$ I. Goldstein, S. Goldstein, $n . d j ., 142$.

${ }^{44}$ M. Kevo, „Počeci logora Jasenovac“, 485. 
Da bi spriječio intervencije Pavelić je 27. lipnja 1942. godine zabranio bilo kome „da (se) u vezi s «Izvanrednom zakonskom odredbom i zapovjedi» od 26. lipnja... u svojim osobnim stvarima, koje imaju značaj intervencije, obraća Glavnom Ustaškom Stanu, jer ni u kojem slučaju neće biti saslušan" ${ }^{45}$ GUS je upozorio sve ustaške dužnosnike, da se svaka intervencija u osobnim stvarima kažnjava smrću. Ovakve drastične, a istodobno i nervozno ponavljanje prijetnje pokazuju da je intervencija bilo i da se, zapravo, zbog korupcije ili osobnih poznanstava vjerojatno i nisu mogle spriječiti. To su znali i molioci, koji su se u nekim slučajevima izravno obraćali Paveliću ili drugim visokim dužnosnicima, kako bi ishodili nešto za što su smatrali da redovitom procedurom ne mogu dobiti. U sačuvanim spisima $u$ većini slučajeva poglavnik ili njegov Ured ne ostavljaju nikakav trag, nego ih prosljeđuju nižim instancama, očigledno u pravilu samo uz usmenu preporuku. ${ }^{46}$ Međutim, kao što je istaknuto niti poglavnikove usmene preporuke niže instance često nisu provodile.

Ponekad se znalo dogoditi da bi došao nalog za pojedine zatočenike da se iz logora preprate na slobodu, ali bi u isto vrijeme stigao i drugi nalog, da se zatočenik potajno ubije, a kroz evidenciju provede da je u izvjesnom vremenskom roku umro od bolesti. ${ }^{47}$

Dragutin Jilek, visoki dužnosnik UNS-a je u istrazi poslije Drugog svjetskog rata, naveo da mu se znalo događati da je kao zapovjednik UNS-a preko Ureda I. izdao nalog da se neku osobu pusti iz logora, a da je mjesto tražene osobe dobio obavijest o njezinoj smrti. Uočljivo je bilo što se je $u$ svim tim slučajevima datum smrti poklapao sa datumom naloga puštanja te osobe na slobodu. Bilo je očito da zapovjednik logora Vjekoslav Maks Luburić nije htio dotičnu osobu pustiti na slobodu, pa ju je dao ubiti. Jilek je u istrazi izjavio da je poslije nekoliko takvih slučajeva promijenio metodu, pa je tada izdavao nalog da se zatvorenik preprati Zaštitnom redarstvu u Zagrebu ili da se uputi u bolnicu „Rebro“ u Zagrebu. Tek tada je izdavao drugi nalog Zaštitnom redarstvu da se dotičnog pusti na slobodu. ${ }^{48}$

\footnotetext{
${ }^{45}$ Novi list, Zagreb, 28. VI. 1941.

${ }^{46}$ I. Goldstein, $n$. dj. 208.

${ }^{47}$ A. Miletić, $n$. dj., (knj. III), 1043.

${ }^{48}$ HDA, RSUP SRH SDS, Elaborat Drage Jileka, 20.
} 


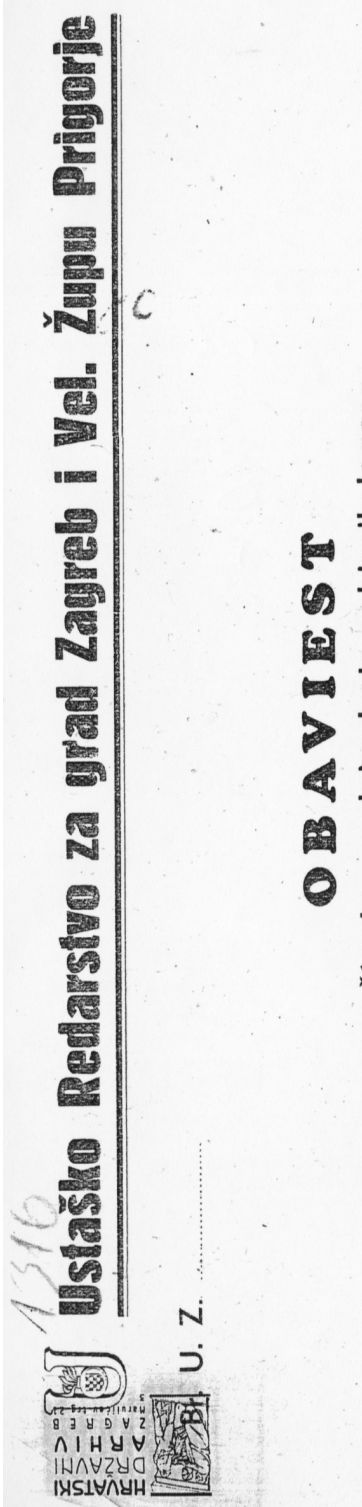

$\frac{\dot{0}}{\circ}$

ڤั

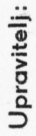

ڤั)

¿

ปั

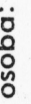

$\stackrel{\oplus}{=}$

วิ

8

离

है

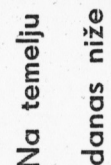

$1 \stackrel{0}{2}$

$\div 8$

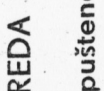

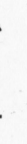

告

0
0
0
0
0
0
0
0
$\frac{N}{2}$
ป
0
0
0
0
0
0
0
0
0
0
0

름

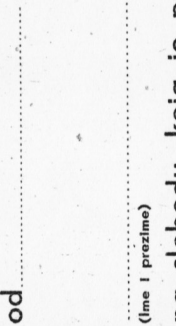

ڤั

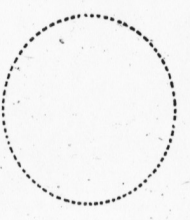

؟

d

ํํำ

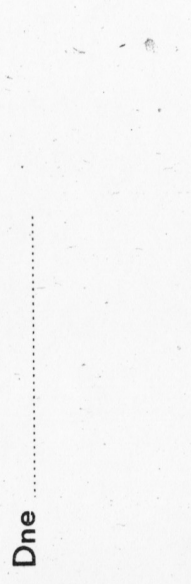

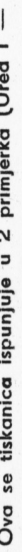

Tipizirani obrazac obavijesti Ustaškog redarstva za grad Zagreb i Veliku župe Prigorje Uredu I UNS-a da je osoba na temelju odpusnice Ureda I. UNS-a bila dopraćena iz logora i puštena na slobodu, HDA, ZIG NDH.

Sredinom srpnja 1942. Ured I UNS-a je naredio da se Marija Rebrača, zatim Marija, Ranka, Darinka i Sava Bojić preprate iz koncentracijskog logora Stara Gradiška Župskoj redarstvenoj oblasti u Brodu. Naime, na molbu Petra Rebrače, stožernog narednika II. samovozne bojne u Brodu, 
Ured I UNS-a odlučio je da se imenovane osobe otpuste iz koncentracijskog logora Stara Gradiška i nakon dovođenja u Župsku redarstvenu oblast $\mathrm{u}$ Brodu puste na slobodu. ${ }^{49}$

Same amnestije, odnosno nekoliko njih za vrijeme trajanja NDH bile su odgovor domaćoj i svjetskoj javnosti kako se logoraši ne ubijaju, nego se njihovi životi štede. Svi pušteni, odnosno amnestirani logoraši, na slobodi su bili budno praćeni, stalno pod paskom, evidentirani kao teški prestupnici i neprijatelji ustaške države i za najmanju sitnicu bili su na udaru novih hapšenja i brzog likvidiranja. ${ }^{50}$

Od ljeta 1944. godine kada je već bila jasna propast nacističke Njemačke i NDH puštene su iz Jasenovca i Stare Gradiške u nekoliko navrata veće skupine zatočenika. Dinko Šakić je na suđenju u lipnju 1999., tvrdio da je za nekog Ivana Heinricha iz Slavonskog Broda puno učinio, tako da su njegovi bliski srodnici Milan i Marko Hirscl koji su bili zatočeni u Jasenovcu bili oslobođeni iz logora. Miroslav Majstorović-Filipović na saslušanju u lipnju 1945., spomenuo je tog Heinricha kao čovjeka sa silnim vezama u njemačkoj komandi, odakle je Luburiću nabavljao neko oružje, pa je „njegovim posredovanjem iz logora na slobodu pušteno nekoliko Židova“. Međutim, na spomenutom popisu amnestiranih logoraša u srpnju 1944., nema niti jednog Hirschla i nema niti jednog Židova. ${ }^{51}$

U kolovozu 1944. puštena su iz logora 32 logoraša. Tada je nakon dvije godine boravka u Jasenovcu pušten i Miljenko Bobanac, koji kaže kako to tada nije smatrao nagradom, jer jedino što bi tada smatrao nagradom bio je „metak u potiljak“. ${ }^{52}$

${ }^{49}$ HDA, Zbirka izvornog gradiva Nezavisne Države Hrvatske (ZIG NDH) IV-10., kut. 90.

${ }^{50}$ Đ. Miliša, $n$. dj., 294.

${ }^{51}$ I. Goldstein, S. Goldstein, $n$. dj., 329. Usp. A. Miletić, $n$. dj., (knj. III), 383.

52 „Sve je bilo organizirano da nas se ubije“, Jutarnji list, Zagreb, 25. III. 1999. 


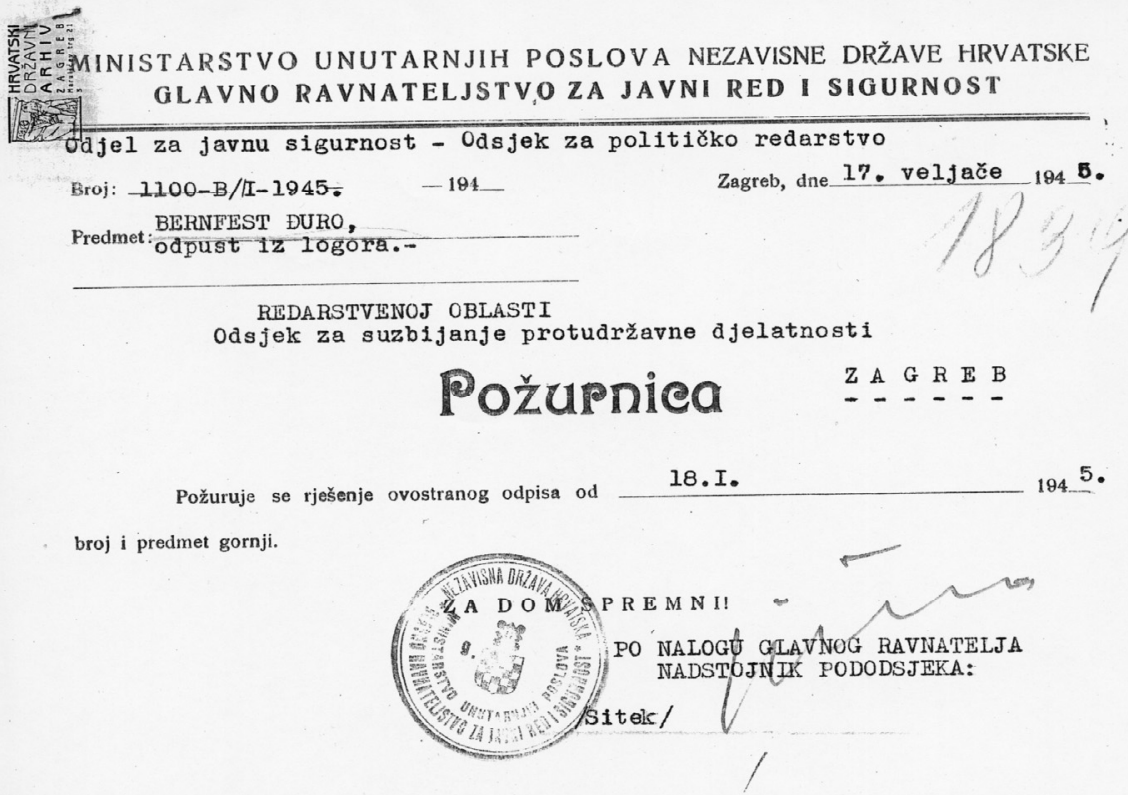

Požurnica za otpust iz logora Đure Bernfesta, početkom 1945. godine HDA, ZIH NDH, II-8

Precizan broj puštenih poslije pomilovanja i amnestije zatočenika i zatočenica iz Stare Gradiške, (kao niti broj likvidiranih zatočenika) nije zasada moguće ustanoviti na temelju dostupnog arhivskog gradiva i literature.$^{53}$ Iz navedenih primjera puštanja zatočenika iz logora Jasenovac i Stara Gradiška vidljivo je da su logoraši povremeno bili pomilovani i puštani svojim kućama. Neki su pušteni i nakon intervencija istaknutih ustaških dužnosnika.

Jedna od značajki logora Stara Gradiška (koji je kako je navedeno u jasenovačkoj skupini logora bio označen kao logor V.) bila je da je u njima boravilo i dosta djece koja su dovedena sa Korduna, Kozare, zatim djeca roditelja koji su poslani na rad u Njemačku. Oko njihovog zbrinjavanja i spašavanja naročito se angažirala Diana Budisavljević, porijeklom Austrijanka, udana za profesora kirurgije na zagrebačkom Medicinskom fakultetu, dr. Julija Budisavljevića. U njezinu akciju spašavanja djece iz logora bio je uključen širi krug ljudi, među njima i Kamilo Bresler iz Odjela za skrb Ministarstva udružbe NDH (ministarstva socijalne skrbi) kao i Hrvatski crveni križ, među čijim članovima je bilo više suradnika Narodnooslobodilačkog pokreta. U nekoliko navrata u vagonima je (iz Stare Gradiške, Mlake

${ }^{53}$ I. Goldstein, S. Goldstein, $n$. dj., 322. Može se procijeniti da je od 1942. do 1945., pomilovanjima bilo obuhvaćeno najmanje 500 zatočenika. 
i Jablanca) stiglo oko 12.000 uglavnom srpske djece koja su bila smještena u Zagrebu u dječjem domu Josipovac, Jastrebarskom Sisku. Osim spašavanja djece D. Budisavljević je veliki trud uložila za očuvanje i otkrivanje identiteta djece i povezivanje roditelja s djecom. U tu svrhu izradila je i kartoteku za oko 12.000 djece. $^{54}$

\section{Razmjene zatočenika}

Jedan od oblika izlaska zatočenika uz logora na slobodu bila je i zamjena, odnosno razmjena zatočenika i zarobljenih partizana za ustaške i njemačke oficire i vojnike koje su zarobljavali partizani. Prema njemačkim podacima od rujna 1942. do travnja 1945. godine na taj je način zamijenjeno oko 2.000 zarobljenika, odnosno zatočenika sa svake strane. Prema partizanskim podacima taj broj iznosi oko 800 sa svake strane. Od navedenih brojeva barem polovica se odnosi na zatočenike i zarobljene partizane koji su se nalazili u jasenovačkom logorskom kompleksu. Logorsko partijsko rukovodstvo u Staroj Gradiški je već početkom 1942. godine nastojalo izvući, odnosno zamijeniti neke zatočene logoraše. Međutim, sa razmjenama se krenulo $\mathrm{u}$ realizaciju tek $\mathrm{u}$ jesen 1942. godine, kada je za mnoge zatočenike bilo kasno, jer su već bili mrtvi. ${ }^{55}$

Od pojedinih malih i lokalnih razmjena na više mjesta u NDH, prešlo se je na organizirane razmjene, pri čemu je najviše logoraša razmijenjeno iz starogradiškog logora. Jedan broj zatočenika i zatočenica je u razmjenu otišao izravno iz Stare Gradiške, a neki su razmijenjeni poslije odlaska u logore Jasenovac ili Lepoglavu. Sama razmjena nije bila važna samo zbog razmjenjenih zatočenika, nego i zbog toga što je preostalim logorašima podržavala nadu u skori izlazak iz logora. Razmjene su se od 1943. godine uglavnom vršile na području mjesta Pisarovina, nedaleko Jastrebarskog i dogovarale su se isključivo između Nijemaca i partizana, na način da bi partizanske jedinice iz Pisarovine javile Nijemcima da imaju određeni broj zarobljenika. Isto tako Nijemci su sami tražili da se razmijene njihovi određeni zarobljenici. Popis zatočenika za razmjenu sačinjavan je u CK KPH i Glavnom štabu NOV i PO Hrvatske i preko veze prethodno poslan Nijemcima. Kada je logorska partijska organizacija u Staroj Gradiški uspjela uspostaviti vezu s KPH, ona je predlagala zatočenike i zatočenice za razmjenu. Ove razmjene je najprije vršio Marijan Stilinović kao predstavnik Glavnog štaba NOV-a koji je izvršio 3-4 razmjene u Pisarovini. ${ }^{56}$ Poslije njega je raz-

${ }^{54}$ Dnevnik Diane Budisavljević 1941.-1945, Fontes - izvori za hrvatsku povijest, (8), Zagreb, 2002.

${ }^{55}$ M. Peršen, $n$. dj., 238.

${ }^{56}$ Marijan Stilinović, Bune i otpori, Zagreb, 1969., 219.-222. 
mjene vršio Josip Brnčić koji je prema osobnoj procjeni razmijenio oko 150200 zatočenika, od čega 50-60 zatočenica. ${ }^{57}$

Od ožujka 1944. godine, pa do završetka rata, tu je dužnost obnašao Boris Bakrač koji procjenjuje da je izvršio razmjenu oko 800-900 zatočenika od kojih nisu svi bili iz starogradiškog logora. Prema Bakračevim podacima izvršene su slijedeće razmjene: u studenom 1943. razmijenjeno je 47 zatočenika iz logora, od toga 8 članova KP, 3 člana SKOJ-a, ostalo simpatizeri; 12. prosinca 1943. razmijenjeno je 32 zatočenika iz logora, od toga 7 članova KP, 2 člana SKOJ-a, ostalo simpatizeri; 18. siječnja 1944. razmijenjeno je 15 zatočenika iz logora, svi članovi KP i 44 druga borca za koje nedostaju podaci; 27. ožujka 1944. razmijenjeno je 5 zatočenika iz logora, svi članovi KP i 16 boraca za koje nema podataka; 25. IV. 1944. razmijenjeno je 32 zatočenika iz logora za 5 Nijemaca i 3 legionara; 27. IV. razmijenjeno je 23 zatočenika iz logora za 23 domobrana; ${ }^{58} 14$. kolovoza 1944. razmijenjeno je 10 zatočenika iz logora., od toga 1 član OK, 1 sekretar KK, ostalo članovi KP, svi iz zagrebačke organizacije. ${ }^{59}$

Bakrač navodi da su se „naši razmijenjeni drugovi nakon zamjene upućivali ili u bolnicu ili na odmor ili u pojedine vojne jedinice ili ZAV$\mathrm{NOH}$, a jedan mali dio drugova upućen je i u Vrhovni štab“. ${ }^{60}$

Sam postupak razmjene vršio se je tako da je predstavnik partizana odlazio na pregovore s Nijemcima u Zagreb. Kada bi sporazum bio postignut Nijemci bi sakupili za razmjenu zatražene osobe u njemačkoj komandi na Zrinjevcu u Zagrebu, gdje bi ih preuzeo predstavnik partizana. Poslije bi ih se kamionom prebacivalo do Pisarovine ${ }^{61}$ Vlasti NDH bile su upoznate s tim razmjenama i tolerirali su ih, ali su ponekad znali praviti neprilike i onemogućavati zamjenu zatočenika iz zatvora i logora koji su bili pod kontrolom ustaša. U pregovorima s partizanima, Nijemci su često isticali da nema pojedinih osoba iz logora koje partizani traže, jer su ih ustaše ubile pod raznim opravdanjima. Tako je primjerice logorski partijski komitet u Staroj Gradiški krajem 1943. godine preporučio za razmjenu Kajtaza (ne navodi se ime) iz Mostara. Kada je zatražen u razmjenu ubio ga je pred ostalim zatočenicima tadašnji zapovjednik logora Stjepan Bosak. Kasnije, Bosak je poslao izvještaj da je Kajtaz umro u logoru od tifusa. ${ }^{62}$

${ }^{57}$ Marijana Amulić, Čedomil Huber, Otpor u logoru Stara Gradiška, Jasenovac, 1980., 186.

${ }^{58}$ Građa za povijest narodnooslobodilačke borbe u sjeverozapadnoj Hrvatskoj 1941.1945.,(Građa SZH) (knj. IX), Zagreb, 1981., 556-560.

${ }^{59}$ M. Amulić, Č. Huber, n. dj. 186.- 187.

${ }^{60}$ Isto.

${ }^{61}$ M. Peršen, $n$. dj., 119.

${ }^{62}$ M. Amulić, Č. Huber, $n$. dj., 185. 
Razmjene su, kao što je ranije rečeno, vršene od jeseni 1942. godine do proljeća 1945. godine. Na temelju dostupnog arhivskog gradiva i postojeće literature nije moguće utvrditi točan broj razmjena.

Jedna od prvih razmjena bila je 23. rujna 1942. kada je razmijenjena skupina od 30 zatočenika-članova i simpatizera partizanskog pokreta na čelu sa Andrijom Hebrangom koji je bio zatočen u jasenovačkom logoru. Oni su razmijenjeni za dvojicu ustaških dužnosnika, Mirka Vutuca, zamjenika, glavnog nadzornika redarstva u NDH i Karla Wagnera, upravitelja Župske redarstvene oblasti u Novoj Gradiški, koje su zarobili partizani. ${ }^{63}$

Prema izvještaju Glavnog stožera ministarstva domobranstva od 5. listopada 1943, Glavnom ravnateljstvu za javni red i sigurnost (odsjek za političko redarstvo), o pregovorima sa partizanskim predstavnicima za razmjenu zarobljenika zamjenjeno je 14 zatočenika iz logora, od toga tri iz Stare Gradiške: Ruža Brnčić, dr. Zvonko Tkalec i Danica Milić. ${ }^{64}$

Dana 11. studenog 1943. kod željezničke postaje Bijela razmijenjeno je pet osoba iz logora Stara Gradiška za pet časnika 4. Gorskog zdruga: Ruža Rupčić za Milana Delača, opkoparskog nadsatnika, Štefica Srdar za Marijana Meleha, opkoparskog satnika, Emica Krajačić (sa dojenčetom od 7 mjeseci), za Josipa Mazaneka, opkoparskog poručnika, Andrija Dabić za Ivana Pocrnića, pješačkog poručnika, Oto Garaj za Martina Obrtlika, opkoparskog zastavnika. ${ }^{65}$

Dana 16. prosinca 1943. godine, su radi zamjene za zarobljenog pukovnika Ivana Klišanića, glavara stožera I. zbornog područja i druge zarobljene časnike, njemačkim vojnim vlastima ustaše predale skupinu zatočenike iz logora Stara Gradiška. Ukupno je dopraćeno i razmijenjeno 54 osobe. ${ }^{66}$

Postupak razmjene zatočenika iz logora često puta nije bio usklađen između organizacije KPH u logoru sa CK KPH. Naime, često se događalo da osobe koje je predložila logorska partijska organizacija uopće ne budu raz-

${ }^{63}$ HDA, Dosije Hebrang, UDB-a za grad Zagreb, spis br. 4, Zapisnik o saslušanju, 25. V. 1948. Pojedini istraživači poput A. Miletića tvrde da se na temelju uvida u dokumente istrage koje je UNS vodio protiv Hebranga može zaključiti da je izdao Partiju i da ga je na partizanski teritorij poslala ustaška policija, međutim takve proizvoljne procjene i zaključci, prema iskazima sudionika tih događaja i dosada objavljenoj literaturi nemaju nikakvog značajnijeg uporišta. Poslije izlaska iz logora i dolaska u partizane, Hebrang je nekoliko puta bio nazočan zamjenama u Pisarovini, kao Brnčićev predstavnik, pod imenom, Ivan Jurišić. O zarobljavanju visokih ustaških funkcionera Mirka Vutuca i Karla Wagnera i zamjeni za Andriju Hebranga, Olgu Kohn, dr. Ivekovića i druge vidi u nizu knjiga i polemika u "slučaju Hebrang": Mile Milatović, Slučaj Andrije Hebranga, Beograd 1952., Dragan Kljakić, Dosije Hebrang, Beograd, 1983., Zvonko Ivanković-Vonta, Hebrang, Zagreb, 1988., Mladen Iveković, Nepokorena zemlja, Zagreb, 1945., N. Kisić-Kolanović, Hebrang-iluzije i otrežnjenja, Zagreb, 1996.

${ }_{64}$ A. Miletić., $n$. dj. (knj. II.), 670.

${ }^{65}$ Isto, 671.

${ }^{66}$ Isto. 684 
mijenjene, nego su zamjene vršene prema osobnim vezama i poznanstvima. Oni koji nisu imali takvih veza s partijskim vrhom koji je sastavljao popis zatočenika za razmjenu gotovo i nisu imali šansi za izlazak iz logora.

\section{Bježanja i pokušaji bježanja zatočenika}

Jedan od načina izlaska iz starogradiškog logora, iako nelegalan, bio je i bjeg zatočenika. Naime, uslijed teških i često puta nepodnošljivih uvjeta života u logoru, veliku većinu zatočenika je neprestano obuzimala misao o pokušaju bijega. Bijeg iz logora nije bio jednostavan, niti lak, jer je sustav osiguranja u samom logoru i izvan njega dosta dobro djelovao. Naime, u samom logoru postojala je straža koja je vršila osiguranje logora izvana i iznutra. Početkom 1943., osnovana je Sigurnosna služba koja je preuzela unutarnje osiguranje logora kao i kontrolu nad svim ulazima. ${ }^{6}$

Zbog toga su mnogi pokušaji bježanja završili neuspjehom, odnosno uhićenjima i pogubljenjima. Tako je na Mihaljevo 1942. godine ubijen književnik Grgur Karlovčan, koji je bio u istrazi radi pokušaja bijega. Naime, G. Karlovčanina je dok je radio na vanjskim radovima, netko prijavio da je s rada htio pobjeći. Zbog toga je zatvoren u samicu, gdje je ležao oko mjesec dana. Pri jednom obilasku i pregledu samica, vidio ga je jedan ustaša u logoru i rekao mu: „Pa ti si još živ“. Navečer, je istog dana u samicu ušao ustaša N. Gagro. Sutra ujutro, Karlovčan je iznijet iz samice, pokriven plahtama na nosilima grobara. ${ }^{68}$

Za vrijeme trajanja ofenzive na Kozaru, kada su u logor dovedeni Srbi iz okolnih sela, bilo je u logoru Stara Gradiška puno Hrvata osuđenih na najveću vremensku kaznu, tri godine, tzv. trogodišnjaci. Oni su htjeli iskoristiti metež koji je nastao prilikom dovođenja Srba u logor. Pokušali su pobjeći, ali su kod izlaza napadnuti strojnicama. Poslije ovog pokušaja, tadašnji zapovjednik logora, ustaški poručnik Nikola Gadžić, izdao je zapovijed da se svi preživjeli "trogodišnjaci“ bace u samice bez hrane i vode, gdje su poludili i poumirali. Većina od njih bili su komunisti iz Zagreba, uglavnom intelektualci. ${ }^{69}$

Ipak, pored neuspjelih pokušaja bježanja bio je određeni broj i onih koji su uspješno izvedeni.

${ }^{67}$ HDA, Zemaljska komisija za utvrđivanje ratnih zločina, Glavni urudžbeni zapisnik, (ZKRZ GUZ), elaborat logor Stara Gradiška, 2018/1-45., kut. 8.

${ }^{68}$ Đ. Miliša, $n$. dj., 264.

${ }^{69}$ HDA, ZKRZ, GUZ, br. 1872/47. 
Primjerice, zagrebački odvjetnik Robert Farkaš, tada već šezdesetogodišnjak pobjegao je jer je obitelj potplatila stražara koji ga je izveo izvan žice i rekao mu "da bježi što dalje može“. ${ }^{70}$

Iz logora se nastojalo pobjeći u raznim situacijama kao npr. prilikom odlaska na poljske radove, odnosno kada su ustaše veći broj zatočenika sprovodili iz logora, a bilo je bježanja i prilikom nedjeljnog odlaska zatočenika na misu u crkvu. ${ }^{71}$ Tijekom 1942. godine, uspjela je pobjeći jedna manja skupina logoraša, tako da su u sumrak, nakon što je sirena objavila znak da svi moraju biti u svojim nastambama, pomoću pripremljenih visokih ljestava uspjeli prijeći visoki zid i pobjeći. ${ }^{72}$

Iz logora se je nastojalo pobjeći najčešće pojedinačno ili zajedno dvojica-trojica zatočenika koji su nastojali dospjeti izvan logora i tako se spasiti. Krajem 1942. godine iz logora su pobjegla trojica logoraša, Židova na čelu sa ing. Mišom Danonom, koji je kasnije ovako opisao svoj bijeg: „Dogovorio sam s Moricom Romanom, trgovačkim pomoćnikom i Salomonom Katanom, vodoinstalaterom, da po nekom izmišljenom poslu, uz pratnju ustaškog stražara pređemo pontonskim mostom u Bosansku Gradišku i da poslije negdje $u$ Bosni ubijemo ustašu i pobjegnemo. Više od trojice nas nije smjelo biti jer su za četvoricu zatočenika koji su išli na vanjske radove određivali dva čuvara za pratnju. ${ }^{\text {"73 }}$ Nakon što su se oslobodili stražara i krijući se prešli preko rijeke Vrbas, usput nađenim čamcem, u okolici Banja Luke naišli su na dijelove I. proleterske brigade. ${ }^{74}$

Za vrijeme zapovijedanja Stjepana Bosaka 1943. godine iz logora je uspjelo pobjeći pet zatočenika muslimanske vjeroispovijesti, među kojima su bili Esad Kapetanović i Remzija Omanović koji su već bili istaknuti ilegalni radnici. Bježanje ove skupine zatočenika organizirao je Nijaz Salihodžić član MK KPJ Bihać, koji je u to vrijeme bio logornik. On je kao musliman, angažirajući ih po vjerskoj liniji, pridobio i dvojicu ustaša muslimana koji su pobjegli u ovoj skupini. Iste večeri je skupina ustaša na čelu s ustaškim poručnikom Stojčićem, kružila logorom. Pitali su zatočenike ima li među njima muslimana, a kada se javio jedan, počeli su ga tući cjepanicama, dok ga nisu ubili. ${ }^{75}$ Ustaše su brzo otkrile da je s bježanjem ove skupine usko povezan N. Salihodžić, te su ga uhitili i odveli, a s obzirom da je pružio otpor odmah je bio ubijen. ${ }^{76}$

\footnotetext{
${ }^{70}$ I. Goldstein, S. Goldstein, $n$. dj., 329.

${ }^{71}$ M. Amulić, Č. Huber, $n$. dj, 113.

${ }^{72}$ M. Peršen, $n$. dj., 247.

${ }^{73}$ Isto.

${ }^{74}$ Isto.

${ }^{75}$ Đ. Miliša, n. dj. 266.

${ }^{76}$ M. Amulić, Č. Huber, $n$. dj., 49.
} 
Albert Maestro je pobjegao u kolovozu 1943., kada su skupinu logoraša i stražara koji su bili u sječi šume napali partizani. ${ }^{77}$

U jesen 1943. godine, po odluci logorskog rukovodstva KPH uspio je pobjeći Drago Zatezalo. Kada je u Jasenovcu 1944. godine otkrivena logorska organizacija KPH, zaprijetila je i opasnost za organizaciju KPH u Staroj Gradiški. Drago Pocem je saznao u ustaškoj primo-predajnoj stanici, koju je popravljao, da u logor Stara Gradiška dolazi iz Jasenovca ustaški agent Branko Cividini i da će istragu početi od Jusufa Sabljakovića i ing. Emerika Bluma. Oni su još istog dana organizirali bijeg iz logora pomoću brodića, kojim je prevožena roba iz Jasenovca u Staru Gradišku i obrnuto. Tada je uspio pobjeći ing. Emerik Blum, dok je Jusuf Sabljaković poginuo. ${ }^{78}$

Prilikom dolaska hrane za skladište u logoru, pojedini zatočenici su išli na istovar vagona u obližnje Okučane. U proljeće 1944. godine logorski je komitet KPH poslao na rad u skladište dvojicu zatočenika, jer su trebali pobjeći po zadatku. Jedan od njih je bio Slovenac, kojeg su zvali nadimkom Kranjc. Poslije nekoliko dana na radu u skladištu, poslani su po robu $u$ Okučane. Premda je s njima išla i ustaška straža, oni su iskoristili povoljne okolnosti i uspjeli pobjeći. Navečer kada su se u logor vratila kola s hranom i kada je počeo istovar iz kola ustaše su počele tući zatočenike, kao osvetu za bježanje ove dvojice zatočenika. Jedna skupina zatočenika je odvedena na saslušanje u sigurnosnu službu logora i tamo je bila udarana, na čemu se je i završilo, jer nitko nije odveden niti ubijen. Olakšavajuća je okolnost bila da su ta dvojica tek došla na rad u skladište, pa su se zatočenici mogli opravdati da nisu znali njihove nakane i planove. Pritom im je pomogao i ustaša nadzornik u skladištu. ${ }^{79}$

Sredinom 1944. godine s ekonomije u Jablancu uspijevaju pobjeći Milan Bogić i Božo Palinić, koji su preplivali Savu i priključili se partizanima na Kozari.

Kada bi netko pobjegao ili pokušao bijeg, sazivani su nastupi u logoru, na kojima je bilo likvidacija, na kojima je bilo nazočno pedesetak uniformiranih osoba, obično nadzornici skupina ili radilišta, časnici nižeg ranga, ali ne i upravnici logora. Jedan od bivših zatočenika ovog logora, Šimo Klaić se sjeća da je mjesečno iz ovog logora pobjeglo pet-šest zatočenika, a za svakog pobjeglog pobijeno je deset logoraša. ${ }^{80}$

Zatočenici su bili svjesni da ne mogu očekivati pomoć izvana i zbog toga su u logoru organizirali partijsku organizaciju koja je sastavila plan

${ }^{77}$ I. Goldstein, S. Goldstein, $n$. dj., 330.

${ }^{78}$ M. Peršen, $n$. dj., 247.

${ }^{79}$ M. Amulić, Č. Huber, $n$. dj., 48.

80 „Pomogao mi je Šakićev brat, ali tako da Dinko ne sazna“, Večernji list, Zagreb, 24. III. 1999. 
samooslobođenja koji je ostvaren tek u proboju logoraša 22. svibnja 1945. godine. Od 600 zatočenika koji su sudjelovali u proboju preživjelo je svega 106. Oko 470 izmučenih i bolesnih zatočenika nije sudjelovalo u proboju, ubijeni su istog dana i spaljeni zajedno s logorskim objektima. ${ }^{81}$

Tijekom četiri godine oko 300 zatočenika uspjelo se spasiti iz jasenovačkog logorskog kompleksa bijegom i u posljednjem proboju, ali ih je još više koji su u tim pokušajima izgubili živote. ${ }^{82}$

Prema popisu živih sudionika NOR-a, izvršenog 32. prosinca 1964. godine na području tadašnje Socijalističke Republike Hrvatske, internaciju u logoru Jasenovac preživjelo je 1184., a u Staroj Gradiški 1270, ukupno 2454 osoba. $^{83}$

\section{Zaključak}

Na temelju svega izrečenog može se zaključiti je da je broj preživjelih logoraša, odnosno onih koji su boravili u Jasenovcu odnosno jasenovačkoj skupini te uspjeli preživjeti i izaći na razne načine slobodu značajan te se može sasvim sigurno mjeriti u tisućama. Kao što je opisano preživjeli logoraši su iz logora izlazili na razne načine: otpuštanjem nakon isteka vremenskog roka na koji su bili osuđeni, pomilovanjima prigodom obilježavanja državnih praznika i vjerskih blagdana, raznim intervencijama, razmjenom između partizanskog pokreta i njemačko-ustaških vlasti, a jedan broj zatočenika se spasio zahvaljujući činjenici da su uspjeli pobjeći iz logora.

Nije moguće ustanoviti precizan broj preživjelih zatočenika jer ne postoji cjelovit popis zatočenika logora jasenovačke skupine koji su preživjeli i spasili se na razne načine. Postoji samo popis dijela zatočenika koji su bili u logoru i izišli iz njega na razne načine.

Suprotno ranijim ocjenama pojedinih istraživača, puštanje zatočenika iz jasenovačke skupine logora nije bila posve rijetka, gotovo zanemariva pojava. Isto tako se na temelju popisa djela preživjelih zatočenika može zaključiti da iz logora nisu puštani samo Hrvati, nego i zatočenici svih ostalih nacija i vjera koji su se nalazili u logoru. Jedan broj zatočenika je poslije puštanja na slobodu otišao svojim kućama, a drugi se pridružio partizanima, sudjelujući u antifašističkom pokretu.

Iz svega navedenoga može se zaključiti da je logorski sustav Jasenovac uistinu bio organiziran kao logor smrti, odnosno „pakao“ iz kojeg se premda teško, povremeno uspijevalo izaći i preživjeti.

${ }^{81}$ Filip Škiljan, „Logorski sustav Jasenovac - kontroverze“, Nezavisna Država Hrvatska 1941.-1945“, zbornik radova, (urednica Sabrina P. Ramet), Zagreb, 2009., 120.

${ }^{82}$ I. Goldstein, S. Goldstein, $n$. dj., 330.

${ }^{83}$ Igor Graovac, „O proučavanju struktura sudionika NOB-a i socijalističke revolucije u Hrvatskoj 1941.-1945.", ČSP, Zagreb, 2/1974., br. 2., 39. 
Davor Kovačić

THE WAYS OUT FROM THE JASENOVAC AND STARA GRADIŠKA DEATH CAMPS 1941-1945

\section{Summary}

The article analyses the was out from the death camps in Jasenovac and Stara Gradiška in 1941-1945. Author crytisise the earlier works of the Yugodslav historiography, which mosly focused its works on the estimations of number of the victims killed in the camps, or decsribing the activities of the illegal Communist organisation inside the camp. All other ascpets of the camps existance and daily routine, including the cases of the detainees which were sent out from the camops, were researched and desribed as rare or random case. 